IRSH 66 (2021), pp. 2 I 5-238 doi:10.1017/So02085902 I000I 46

(C) The Author(s), 202 I. Published by Cambridge University Press on behalf of the Internationaal Instituut voor Sociale Geschiedenis

\title{
A Well-Adjusted Debt: How the International Anti-Debt Movement Failed to Delink Debt Relief and Structural Adjustment
}

\author{
HÉ L È E B A I L L O T \\ CESSP, Université Paris I Panthéon-Sorbonne \\ Paris, France \\ E-mail: hbaillot@gmail.com
}

\begin{abstract}
This article analyses the process by which the issues of debt and structural adjustment were redefined by a plurality of actors, from institutional experts to activists, during the I980s and I990s. Although it mainly focuses on the I990s, when the Jubilee 2000 campaign emerged, blossomed, and died, it takes into account the institutional mobilization preceding it. It then points to the need to think about the dynamics of competition and the division of labour among international players. While the leading Jubilee 2000 coalition in the Global North opposed debt on economic and religious grounds, African anti-structural adjustment programme (SAP) activists who joined the Jubilee Afrika campaign promoted an alternative framework: according to them, debt was not just economically "unsustainable"; it was first and foremost "illegitimate", as were any conditions attached to its reduction, beginning with the implementation of SAPs. The story of the anti-debt campaign is the story of their failure.
\end{abstract}

The Greek sovereign debt crisis emerged at the end of 2009: the new government of Georges Papandréou announced a budget deficit of i 2.7 per cent, an amount that far exceeded those stated by his predecessor, thus unveiling the long-time masking of Greek public accounts. As a result, credit rating agencies downgraded Greek debt, which lost its triple A mark, and Greek debt obligations flooded the secondary debt market without finding any buyers. In April 2010 , with a public debt amounting to 350 billion euros, that is, I 50 per cent of the country's GDP, Greece was on the verge of defaulting. Its government turned to the International Monetary Fund (IMF) and the European Union (EU), who agreed on an initial bailout programme. Reaching the amount of I I $\circ$ billion euros, a loan was granted in exchange for the implementation of structural reforms: a wage freeze in the public sector; pensions cuts; and a steep rise in VAT. In the following years, two further bailout programmes were signed, leading to major protests and social unrest throughout the country. In April 2015, early parliamentary elections brought to power the 
leftist coalition Syriza, and a few months later the Greek parliament established the Truth Committee on Public Debt, whose mandate was to investigate the origin and contraction of Greek public debt. Chaired by Zoe Konstantopoulo (who then served as head of the Hellenic Parliament) and scientifically coordinated by Éric Toussaint (head of the Committee for the Abolition of Illegitimate Debt (CADTM)), the committee issued a report stating:

The [adjustment/bailout] programs consist of neoliberal policy measures that involve deep spending and job cuts in the public sector, extended deregulation of the private sector, tax increases, privatizations, and structural changes (misleadingly called "reforms"). These internationally imposed measures, supposedly aimed at reducing the country's budget deficit and public debt to sustainable levels, have pushed the economy into a deep recession - the longest recession experienced in Europe during a period of peace. Millions were thrown into poverty, unemployment, and social exclusion, while human rights, particularly economic and social rights, were grossly undermined. Public services and infrastructure such as schools, hospitals, courts, and municipalities around the country have been merged, shut down, or otherwise suffocated, in order to achieve fiscal targets specified by the creditors that have been widely criticized as unacceptable and unrealistic. ${ }^{\mathrm{I}}$

The entanglement of public debt and structural economic reforms, of which the Greek case is a cruel example, is not new, and one can only be struck by the similarities between the situation faced by some European countries in the aftermath of the financial crisis of 2008 and the situation encountered by a majority of African countries some thirty years ago. Throughout the I 980 s and I990s, many African countries, facing outstanding levels of debt, were compelled to implement structural adjustment programmes (SAPs) under the auspices of the IMF and the World Bank. Inspired by the Washington Consensus, such programmes featured national currency devaluations to enhance export earnings and discourage imports, the privatization of government-controlled industries and services, and cuts in government budgets. $^{2}$

Launched in 1996, Jubilee 2000 was the first transnational anti-debt campaign. Gathering activists from the Global North and the Global South, its goal was to achieve massive debt reduction for poor countries by the end of the year 2000, as per the biblical principle of jubilee. While activists mostly focused on debt, a peculiar level of attention was given to the issue of SAPs. Campaigners demanded that debt cancellation take place "under a fair and transparent process" and with no attached conditionalities (i.e. the implementation of structural adjustment policies in southern countries benefiting from debt relief agreements). Their mobilization resulted in concrete outcomes with

I. The Truth Committee on Public Debt, Preliminary Report, i 8 June 20 I 5 , p. 7.

2. Yves Dezalay and Bryant Garth, "Le "Washington Consensus", Actes de la recherche en sciences sociales, I 2 I-I 22 (I998), pp. 3-22. 
the launch, in June 1999, at the G7 Cologne summit, of a new international debt relief initiative: the enhanced Heavily Indebted Poor Countries initiative (HIPC II, Figure I). ${ }^{3}$

Not surprisingly, the "success" of Jubilee 2000 lies at the heart of the scholarship on the campaign: scholars who became interested in Jubilee were mostly driven by the same incentive, that is, underlying factors leading to success. ${ }^{4}$ Coming from diverse backgrounds - political economy, political science, and anthropology - they offered rich and diverse analytical frameworks to understand why Jubilee achieved what it did. Although they produced a rich corpus that shed light on different facets of this transnational movement, they did not avoid some shortcomings. Firstly, they tended to forget, or at least to downplay, the fact that the issue of success was highly controversial within the Jubilee movement itself. If some activists rejoiced in the campaign's results, others, mainly from the Global South, denounced HIPC II as a "cruel hoax". Of course, the existence of conflicting interpretations among activists is not uncommon - other articles gathered in this Special Issue show it well - and social movement scholars have long shown that movement participants may have different perceptions of what counts as success. ${ }^{5}$ But the split that hit Jubilee 2000 just a few months after the Cologne agreement turned it into a paradigmatic case of a conflicted campaign; ${ }^{6}$ in November 1999 , southern activists gathered in Johannesburg and decided to continue the mobilization on their own under the new banner of Jubilee South. Secondly, while acknowledging that Jubilee was a genuine transnational campaign, scholars tended to mainly focus on northern activists; field research was mostly conducted in the United Kingdom, where the international secretariat of the campaign

3. For a study of the way in which measurements of over-indebtedness have been constructed, used, and modified in the context of multilateral initiatives for Heavily Indebted Poor Countries (HIPC), see Marc Raffinot, "Mesurer le surendettement des pays à faible revenue. Technique, éthique ou politique?”, Revue Tiers Monde, I (2013), pp. 5 I-70.

4. See, for example, André Broome, "When Do NGOs Matter? Activist Organizations as a Source of Change in the International Debt Regime", Global Society, 23 (2009), pp. 59-78; Joshua W. Busby, Moral Movements and Foreign Policy (New York, 2010); Paula Goldman, From Margin to Mainstream: Jubilee 2000 and the Rising Profile of Global Poverty Issues in the United Kingdom and United States (Ph.D., Harvard University, 2010); Noha Shawki, "Issue Frames and the Political Outcomes of Transnational Campaigns: A Comparison of the Jubilee 2000 Movement and the Currency Transaction Tax Campaign”, Global Society, 24 (2010), pp. $203-230$.

5. Marco Giugni, "Was it Worth the Effort? The Outcomes and Consequences of Social Movements”, Annual Review of Sociology, 24 (1998), pp. 37 I-393.

6. Some works, mostly coming from scholars involved in the anti-debt movement, have nevertheless dealt with this important issue: Elizabeth Donnelly, "Proclaiming Jubilee: The Debt and Structural Adjustment Network", in Sanjeev Khagram, James V. Riker, and Kathryn Sikkink (eds), Restructuring World Politics: Transnational Social Movements, Networks, and Norms (Minneapolis, MN, 2002), pp. I55-180; Jean Somers, "The Dynamics of South/North Relationships within Transnational Debt Campaigning”, Interface, 6 (2014), pp. 76-102. 


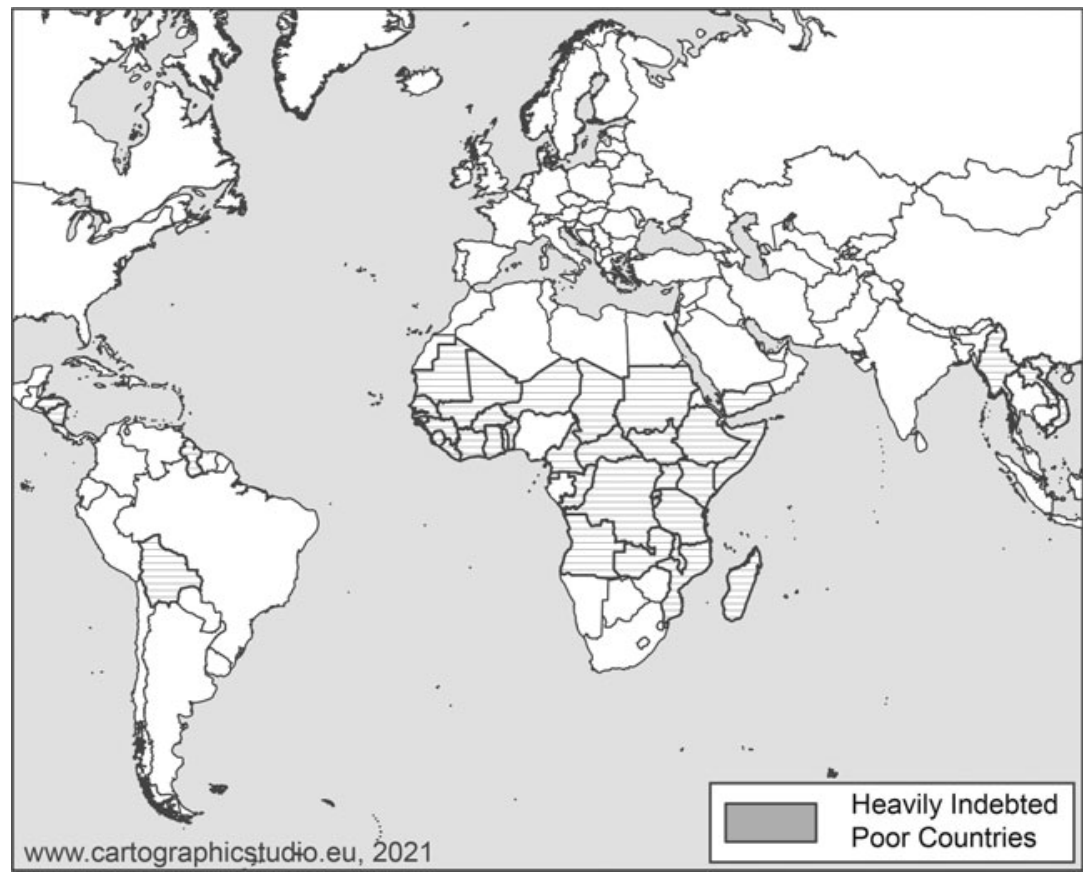

Figure I. Countries potentially eligible for debt relief under the HIPC II initiative (1999).

was based, and in the United States, where the IMF and World Bank are headquartered. As a result, the participation of southern campaigners in the anti-debt movement, especially African activists, remains largely overlooked, a fact that reminds us that the sociology of transnational social movements is still mainly focused on Western civil societies - despite some commendable exceptions. ${ }^{7}$

Drawing on field research conducted during my Ph.D. thesis in the United States and United Kingdom as well as in Uganda and the Philippines between $20 \mathrm{II}$ and $2017,{ }^{8}$ this article aims at presenting and analysing some important

7. Franklin D. Rothman and Pamela E. Oliver, "From Local to Global: The Anti-Dam Movement in Southern Brazil, 1979-1992", in Jackie Smith and Hank Johnston (eds), Globalization and Resistance: Transnational Dimensions of Social Movements (New York, 2002), pp. I I 5-I32; Lesley J. Wood, "Bridging the Chasms: The Case of Peoples' Global Action", in Joe Bandy and Jackie Smith (eds), Coalitions Across Borders: Transnational Protest and the Neoliberal Order (Lanham, MD, 2005), pp. 95-1 17; Janet Conway, Edges of Global Justice: The World Social Forum and Its "Others" (London [etc.], 20I2); Johanna Siméant, Marie-Emmanuelle Pommerolle, and Isabelle Sommier (eds), Observing Protest from a Place: The World Social Forum in Dakar (2011) (Amsterdam, 2015), pp. 137-1 56.

8. Hélène Baillot, "Nous ne devons rien, nous ne paierons rien". Jubilee 2000 et la redéfinition du mode de problématisation de la dette des pays pauvres (1996-2000), (Ph.D., Université Paris I Panthéon-Sorbonne, 2017). 
controversies that surrounded the construction of poor countries' debt as a public problem. To do so, it mostly relies on a large range of militant sources gathered from Jubilee USA, Jubilee UK, Jubilee Uganda, and Freedom from Debt coalitions (in the Philippines); minutes of meetings, flyers, newsletters, advocacy materials, faxes, and emails were systematically collected over the period 1996-2000. A careful analysis of this rich documentation along with interviews conducted with former Jubilee activists helped me better understand not only the different positions national Jubilee coalitions had on debt, but also how their positions evolved over time. It also gave me a good sense of the tensions that arose between the different coalitions, especially although not exclusively between northern and southern campaigners.

As I will demonstrate in this article, those tensions, which eventually led to a split between northern and southern campaigners, were not merely over the question of numbers (i.e. how much debt relief should be granted), but arose from a difference in underlying principles. While the leading coalitions in the Global North mainly opposed debt and structural adjustment on economic and religious grounds, African activists who joined the Jubilee Afrika campaign promoted an alternative framework: according to them, debt was not just economically "unsustainable"; it was first and foremost "illegitimate", as were any conditions attached to its reduction, beginning with the implementation of SAPs. Debt thus became a metaphor to denounce the long-term and ongoing domination of the Global North. This was especially the case as many African activists increasingly expressed the feeling that the domination of the Global North was being reproduced within the Jubilee 2000 campaign itself. While truly transnational, Jubilee 2000 remained dominated by northern coalitions, especially Jubilee UK and Jubilee USA. It is thus essential to pay particular attention to the issues of power imbalances and division of labour among international activists. Only through such a lens can we better understand how and for whom debt and structural adjustment became - and remain - an issue.

Although this article mainly focuses on the I 990 s, when the Jubilee 2000 campaign emerged, blossomed, and died, it also takes into account the institutional mobilization that immediately preceded it. While often considered to be activists' "adversaries", experts in economics working for international organizations played an important role in framing debt and structural adjustment as a problem.

\section{HOW POOR COUNTRIES' DEBT AND STRUCTURAL ADJUSTMENT BECAME A PUBLIC PROBLEM: \\ THE EARLY STAGES}

Before anti-debt activists launched massive protests in the inner cities of Birmingham or Cologne, and before they started widely circulating petitions in favour of debt relief, experts, and consultants, acting from within the institutional framework, were the first to seize upon the debt issue and to frame it 
as a problem. Their mobilization, although confined to bureaucratic arenas, paved the way for Jubilee 2000 and provided anti-debt activists with solid economic expertise, on which they heavily relied.

\section{The role of institutional experts in the early problematization of debt and structural adjustment}

In the early I990s, the international financial institutions expressed great relief that the international systemic crisis they had feared had not occurred. Severe economic and financial difficulties faced by many South American countries in the wake of Mexico's sovereign default appeared to have been overcome thanks to the launch of two massive rescue plans, ${ }^{9}$ that is, the Baker and Brady plans (1985 and 1989), both designed by the United States Treasury. ${ }^{\mathrm{IO}}$ But while the World Bank and the IMF were celebrating victory, ${ }^{\mathrm{II}}$ other institutional actors started expressing their concerns: according to them, the economic and financial crisis, far from being over, was now striking another group of states, namely the heavily indebted poor countries. Among the institutional actors who first coined poor countries' debt as a problem were experts and consultants working for United Nations agencies such as the United Nations Development Programme (UNDP), the United Nations Conference on Trade and Development (UNCTAD), and the United Nations Children's Fund (UNICEF). One can also mention the role of experts working for national aid agencies such as the Swedish International Development Authority (SIDA) as well as for a few think tanks active in the field of international development, including the Institute of Development Studies or the Institute of Policy Studies, both headquartered in the United Kingdom. Although quite diverse, they shared common characteristics and can be considered as a small elite of development economists. Trained at some of the most prestigious universities (such as Yale, Cambridge, MIT, and the London School of Economics), they tended to circulate widely across the private and the public sector, across states and international organizations, and among non-governmental organizations (NGOs) and think tanks. Stephany Griffith Jones, for example, before joining the Institute of Development Studies where she worked on poor countries' debt crisis, started her career in 1970 at the Central Bank of Chile and then worked at Barclays Bank International in the UK. In the meantime, she acted as a consultant to

9. Vinod K. Aggarwal, “Interpreting the History of Mexico's External Debt Crises”, in Barry Eichengreen and Peter H. Lindert (eds), The International Debt Crisis in Historical Perspective (Cambridge, I989), pp. I40-I 88.

ı. Marc Raffinot, "Dette des pays émergents. Traitements innovants et multiplication des crises", in Marc Raffinot, La dette des tiers mondes (Paris, 2008), pp. 77-90; Tony Killick and Simon Stevens, "Mechanisms for Dealing with Debt Problems", in Zubair Iqbal and Ravi Kanbur (eds), External Finance for Low-Income Countries (Washington, DC, 1997), pp. I45-174.

I I. World Bank, World Debt Tables (Washington, DC, I989). 
governments and to international organizations including UNICEF and the World Bank. Another example is Percy Mistry, who, after serving as a financial analyst at the World Bank for fifteen years (197I-1986), worked as a consultant for various international organizations and as an adviser on matters of debt, macro-economic management, and structural adjustment for governments in Asia and Africa. At the same time, he pursued a successful career in the private sector, with such positions as CEO of Synergy Power Corporation, Senior Advisor to Europa Partners Ltd, and Director of the JP Morgan Emerging Markets Investment Trust. Trained at Cambridge and Yale, Richard Jolly, for his part, acted as economic adviser to the government of Zambia (1964-1966) before taking up the direction of the Institute of Development Studies (1972-I98I). He then became Deputy Executive Director of UNICEF (1982-I996), a position he held when he seized upon the issue of debt and structural adjustment.

The involvement of these actors - described by Deacon and Hulse as "global social reformist[s]" ${ }^{\prime 2}$ - in the issue of debt and structural adjustment emerged in a specific context. In the early I990s, actors involved in the field of international development were facing a crisis of legitimacy. They had all seen their mission and their very reason for being questioned due to the poor results of the development policies conducted over the previous decade: economic stagnation, the dramatic rise of indebtedness, and the persistence of poverty were such that the I 980 s had been qualified as a "lost decade" for development. Critical voices raised the inefficiency of international aid. Robert Cassen, a former World Bank senior economist, asked, sceptically, "Does Aid Work?" in a report on foreign aid that had a broad audience. ${ }^{13}$ Furthermore, the I 980 s were marked by the increasing power of international financial institutions (IFIs); the liberal turn taken by IFIs deeply affected the role of UN agencies, who saw their capacity reduced and their role marginalized on the international stage. ${ }^{14}$

It was therefore precisely in trying to defend the very meaning of their mission that experts working in the development field shaped debt and structural adjustment into a problem. If development policies did not achieve their expected positive effects, it was not because "aid doesn't work" but because other elements, lying beyond their scope, hampered its proper implementation, namely, debt and structural adjustment policies. By making debt a problem, they intended to transfer the responsibility for development failures to the two major international institutions in charge of dealing with international

I 2. Bob Deacon, Michael Hulse, and Peter Stubbs, Global Social Policy: International Organizations and the Future of Welfare (London, 1997).

I3. Robert Cassen et al., Does Aid Work? (Oxford, I986).

I4. Deacon, Hulse, and Stubbs, Global Social Policy; Yves Dezalay and Bryant G. Garth, La mondialisation des guerres de palais. La restructuration du pouvoir d'État en Amérique latine, entre notables du droit et "Chicago Boys" (Paris, 2002). 
finance: the IMF and the World Bank. The construction of the debt problem during the I 980 s and early I 990 s must therefore be understood in the light of the dynamics of competition that opposed, within the international arena, a development pole, declining at the time, to a financial pole, led by the "Unholy Trinity", is which asserted a dominant position in a world marked by the end of the Cold War and the expansion of neoliberalism. ${ }^{16}$

The global social reformists experienced serious difficulties in making themselves heard by the IFIs officials, who, in 1989 , were still asserting that "there [was] no generalized debt crisis". ${ }^{17}$ For these institutions, who were in charge of managing poor countries' debt, to qualify the situation as a "debt crisis" would have meant accepting a share of responsibility, if not in the origin of the crisis then at least in its resolution. ${ }^{18}$ That was a risk those institutions were not eager to take. To make their voices heard, the development experts participated in - and sometimes even organized - international conferences. From 7-IO July 1989, for example, Dubrovnik hosted the Conference on Future International Financial Monetary and Trade Cooperation for Development, where Steffany Griffith Jones, then a researcher at the Institute of Development Studies, was invited to speak. On 9-10 June 1992, Percy Mistry helped organize a workshop on the "Functioning of the International Monetary System" for the Forum on Debt and Development (FONDAD). Held at the Netherlands Ministry of Foreign Affairs in The Hague, the workshop included Stephany Griffith Jones along with John Williamson, the economist who coined the term "Washington Consensus", and Johannes Witteveen, a former IMF managing director. Another strategy was to write and disseminate reports. Some provided important ammunition for anti-debt activists, such as Adjustment with a Human Face, written for UNICEF by Andrea Giobanni Cornia, Richard Jolly, and Frances Stewart; ${ }^{19}$ Multilateral Debt: An Emerging Crisis? written for FONDAD by Percy Mistry; ${ }^{\circ} A$ Way Out of the Debt Trap, written for SIDA; ${ }^{21}$ and the UNCTAD Annual Report $1993 .{ }^{22}$ In spite of several important differences, all these reports shared a common central argument: the situation in poor countries, already very serious, was

I5. Richard Peet, Unholy Trinity: The IMF, World Bank and WTO (London, 2003).

I6. Bruno Jobert (ed.), Le tournant néo-libéral en Europe. Idées et recettes dans les pratiques gouvernementales (Paris, 1994).

17. Ibid.

I 8. David Ambrosetti and Yves Buchet de Neuilly, "Les organisations internationales au cœur des crises”, Cultures E Conflits, 75 (2009), pp. 7-I4.

19. Giovanni Andrea Cornia, Richard Jolly, and Frances Stewart, Adjustment with a Human Face: Protecting the Vulnerable and Promoting Growth (Oxford, 1987).

20. Percy Mistry, Multilateral Debt: An Emerging Crisis? (The Hague, 1994).

2. SIDA, A Way Out of the Debt Trap: Proposals to Remove the Debt of the Poorest and Most Indebted Countries (Stockholm, 1992).

22. UNCTAD, Trade and Development Report (New York, 1993). 
worsening at an alarming rate. The total debt of sub-Saharan countries was such that it had become a major impediment to economic growth:

A high level of debt has a generally detrimental effect on a country's macroeconomic situation inasmuch as it affects inflation, interest rates and exchange rates. A high level of indebtedness increases budget deficits, which may fuel inflation. A high rate of inflation leads to high interest rates, which can deter investments. The foreign exchange rate will then be difficult to defend. Economic problems and heavy indebtedness also lead to political unrest. All these factors discourage foreign investment. ${ }^{23}$

The act of "naming" the problem came along with the attribution of blame. ${ }^{24}$ On that matter, all agreed on the fact that IFIs bore a great share of the responsibility and denounced "the pyramiding of multilateral debt", ${ }^{25}$ which was deemed all the more problematic as international creditors imposed harsher condition on debtor countries than bilateral ones:

The penalties for default or delay in making debt service payments to the IFI (and particularly to the World Bank and IMF) are severe. They can, for example, result in the suspension of debt relief agreements and the cessation of most new aid flows - not only from the multilateral institutions themselves but from bilateral agencies as well - thus resulting in cutting off the only lifeline that the poorest countries have opened to them for financing critical imports. Most developing countries have therefore chosen to continue paying multilateral debt service to the extent that they are able, even when it absorbs a large portion of any new credits or grants they might receive from any source. ${ }^{26}$

In the various reports, the global social reformists also criticized the design of SAPs. Poorly conceived, they proved to be inefficient in improving the economic performance of indebted countries:

The economic outcomes of these loans and the programs they financed have not yet generated the levels of sustainable growth required, nor sufficiently enhanced export earnings, to cover the additional debt service burdens imposed, as quickly as had been anticipated when these loans were made. ${ }^{27}$

Worse, SAPs were held responsible for the increase in the outstanding debt:

Between $1980-87$ the outstanding stock of multilateral (including IMF) debt to sub-Saharan Africa increased by some $\$ 25$ billion, most of it applied to lending for structural or sectoral adjustment. Between 1987-92, the debt stock increased by roughly a further $\$ 16$ billion while total debt service obligations to multilateral

23. SIDA, $A$ Way Out of the Debt Trap, p. Io.

24. William L.F. Felstiner, Richard L. Abel, and Austin Sarat, "The Emergence and Transformation of Disputes: Naming, Blaming and Claiming”, Law and Society Review, is (1980-1981), pp. 63I-654.

25. Mistry, Multilateral Debt, p. 9.

26. Ibid., p. I6.

27. SIDA, $A$ Way Out of the Debt Trap, p. I2. 
institutions (including the IMF) were about $\$ 2.4$ billion higher; having increased from under \$I billion in 1980 to nearly $\$ 3.4$ billion in $1992 .{ }^{28}$

In their reports, the global social reformists advocated in favour of debt relief for the poorest countries and insisted on the importance of multilateral debt relief. From different angles, they also called for reform in the design of SAPs. Experts at SIDA, for example, requested a revision of the economic policy calendar: for major reforms to be fruitful, indebted states should be given more time to repay their loans. For their part, UNICEF experts advocated for better inclusion of the most vulnerable people in the design of SAPs and called for "adjustment with a human face". ${ }^{29}$

The mobilization of these development experts, although muffled and confined to bureaucratic arenas, attracted attention from World Bank and IMF officials, who, in September 1996, agreed on the launch of a joint programme: the Heavily Indebted Poor Countries initiative (HIPC). The intent of this initiative was to provide an exit from the rescheduling process by reducing debt to "sustainable" levels so that it was not an impediment to growth. But while the HIPC initiative opened the way for the reduction of multilateral debt, it also strengthened the link between debt reduction and structural adjustment. Indeed, in order to benefit from debt relief under HIPC, a country had to demonstrate its strong commitment to major IMF and World Bank economic reforms for at least six years (qualifying period).

The global social reformists thus opened a breach into which Jubilee 2000 activists stepped. They also developed and circulated solid economic expertise on debt and structural adjustment in poor countries, on which Jubilee activists heavily relied.

The emergence of a transnational social movement against the debt:

The birth and rise of Jubilee 2000

Launched in I996, Jubilee 2000 was the first international campaign advocating for the cancellation of the public debt of the poorest countries. Initiated by international NGOs, anti-poverty groups, and church-related agencies such as Tearfund and Christian Aid, Jubilee 2000 called for the "cancellation of the backlog of unpayable debt for the world's poorest countries - which either cannot be paid or can be paid only with enormous human suffering". 30 To achieve their goals, Jubilee 2000 activists engaged in advocacy and intense lobbying with international financial institutions and the heads of state of the most industrialized nations. Along the way, the campaign gained the

28. Mistry, Multilateral Debt, p. I7.

29. James P. Grant, "Introduction", in Giovanni Andrea Cornia, Richard Jolly, and Frances Stewart, Adjustment with a Human Face, p. 4.

30. Jubilee 2000 Coalition, How It All Began: Causes of the Debt Crisis, 1998. Jubilee UK archives, Newcastle. 
endorsement of several celebrities. Bono, Bob Geldof, Youssou N'Dour, Giorgio Armani, to mention a few, took active part in the campaign by attending protests, creating and selling T-shirts in favour of debt relief, or organizing concerts. At the 1999 Brit Awards ceremony, Jubilee 2000 was honoured with the Freddie Mercury Award and received the public support of Keith Flint, David Bowie, and Bono. The latter even took part in the international Jubilee 2000 delegation invited to meet with Pope John Paul II.

In May 1998, a large protest was organized in Birmingham that was attended by about 70,000 activists. In June I 999, 40,000 demonstrators formed a human chain around Cologne, Germany, and a petition with 17 million signatures in favour of debt relief (the largest petition in history at the time) was presented to the heads of state of the most industrialized countries:

We, the undersigned, believe that the start of the new millennium should be a time to give hope to the impoverished people of the world. To make a fresh start, we believe it right to put behind us the mistakes made by both lenders and borrowers, and to cancel the backlog of unpayable debts of the most impoverished nations. We call upon the leaders of lending nations to write off these debts by the year 2000. We ask them to take effective steps to prevent such high levels of debt building up again. We look for a new beginning to celebrate the millennium. ${ }^{31}$

Heavily relying on the expertise produced by the "global social reformists", Jubilee 2000 campaigners mostly framed the debt as an economic issue. Debt was considered as "unsustainable" and Jubilee 2000 campaigners advocated in favour of debt relief on such grounds. Some Jubilee 2000 campaigners also relied on religious arguments and called for "debt forgiveness". In December 1999, for example, Jubilee USA organized a candlelight vigil:

Candles placed within paper bags bearing the names of the indebted countries targeted for debt forgiveness by the J2000 campaign will be lit one by one. As each country's candle is lit, a prayer will be offered for the people there and for the forgiveness of the country's debt. ${ }^{32}$

While Jubilee 2000 cannot be confined to a religious campaign, one must acknowledge the central position of churches and faith-based NGOs in the birth and rise of the Jubilee movement. Jubilee USA, one of the most important national coalitions (not least because of its proximity to the IMF and World Bank headquarters and the US Congress) comprised many of the larger US national churches (the Episcopal Church, the Methodist church, the National Catholic Conference of Bishops, and the Presbyterian Church), as well as Christian relief agencies (Catholic Relief Services and Lutheran World Relief) and faith-based NGOs such as Bread for the World, an ecumenical Christian advocacy NGO, and the Center of Concern, a Jesuit think tank.

31. Jubilee 2000 petition. Jubilee UK archives, Newcastle.

32. Interview with Marie Dennis, Maryknoll Office for Global Concern/Jubilee USA, Washington, DC, June $20 \mathrm{I}$ I. 
The notion of Jubilee itself comes from the Bible, from the book of Leviticus, and describes an event that occurred every fifty years when slaves were freed, land was restored, and debts were cancelled. The idea of linking debt relief to the new millennium and the religious idea of Jubilee was proposed in the early 1990 s by Martin Dent, a British professor at Keele University. ${ }^{33}$ Together with Bill Peters, a former British ambassador to Uruguay and High Commissioner to Malawi, Martin Dent started promoting the Jubilee principle that he considered a "Theological Help in an Urgent Crisis". ${ }^{34}$

While debt was the main focus of the Jubilee campaign, campaigners also took on the issue of SAPs. In its advocacy work, the Jubilee 2000 international secretariat devoted significant attention to the issue of structural adjustment through the perspective of "debt conditionalities". For example, the main booklet of the campaign, The Debt Cutter Handbook, included a double page on the issue of SAPs. A paragraph entitled "SAPping the Poor" described such programmes as "IMF economic policies imposed by western creditors whose ultimate purpose is (a) to generate hard currency to repay debt and (b) to open up developing country markets to foreign imports". ${ }^{35}$ Because of the strong presence of faith-based organizations, SAPs were even criticized with the help of religious arguments. Participants in Jubilee 2000 religious workshops were invited, for example, to "compare the provisions in the biblical texts to the structural adjustment policies of the international financial institutions", in which "the poor pay the debt as governments cut the lifelines of health, education, basic food subsidies and ultimately, hope". ${ }^{36}$

From its inception in London in 1996, Jubilee 2000 was intended to become a transnational campaign. Its founding members, as well as its first funder, ${ }^{37}$ considered that only a worldwide movement would be able to put efficient pressure on the decision makers concerned with the debt issue, that is, $\mathrm{G}_{7}$ countries and IFIs. Priority was given to two paths of internationalization: the $\mathrm{G}_{7}$ countries themselves and the poorest indebted countries. As for the first, the young secretariat of Jubilee 2000 thought that pressure would be more efficient from the "inside", that $\mathrm{G}_{7}$ leaders would be more responsive

33. Baillot, Nous ne devons rien, nous ne paierons rien, pp. 289-3 18; Goldman, From Margin to Mainstream, pp. 56-72.

34. Martin Dent, Jubilee 2000: A New Start for Debt Ridden Developing World, 8 May 1998, p. 9. Jubilee UK archives, Newcastle.

35. Jubilee 2000 UK, The Debt Cutter's Handbook (London, I996), p. 32. Jubilee UK archives, Newcastle.

36. Rev. Rebeca Dudley, "Debt as a Challenge to Faith", in Jubilee 2000 UK, The Debtcutter Handbook (London, I998), p. 2.

37. The $£ 50,000$ grant provided by the Tudor Trust to the emerging Jubilee 2000 in 1996 was conditioned on the internationalization of the movement. Jubilee UK, Notes of a Meeting Held at the Tudor Trust, London, 6 March I996. Jubilee UK archives, Newcastle. 
if their own constituencies were nationally involved. $3^{8}$ During the years 1996 and 1997, Jubilee expanded to Germany, the United States, and Canada. Churches and international organizations such as Oxfam, Tearfund, and Action Aid, who were part of the secretariat of Jubilee 2000, played a key role in this process. ${ }^{39}$

As for the second, the secretariat of Jubilee 2000 considered that getting southern indebted countries involved would help legitimize the anti-debt movement in the eyes of northern campaigners; they believed that only transnationalization would help bring some moral suasion to a campaign that otherwise would run the risk of appearing as another movement for the poor without the poor. Because Africa was considered the continent most victimized by globalization, most concerned with indebtedness, and most affected by unfair economic policies imposed by the World Bank and the IMF, the secretariat worked hard to get African countries on board.

In 1999, Jubilee 2000 was a loosely affiliated campaign of around sixty national coalitions. But as the campaign was gaining momentum, tensions appeared, especially although not exclusively along the North-South divide. ${ }^{4}$ While the leading coalition in the North mostly opposed debt and structural adjustment on economic and religious grounds, African activists who joined the Jubilee Afrika campaign started to promote an alternative framework. Debt was not just economically "unsustainable"; it was first and foremost "illegitimate", as were any conditions attached to its reduction, beginning with the implementation of SAPs.

\section{“DON'T OWE! WON'T PAY!” AFRICAN ANTI-SAP ACTIVISTS WITHIN THE JUBILEE CAMPAIGN}

While most academic works devoted to Jubilee 2000 tend to adopt a monolithic approach, thus insisting on the "success" of the movement, a greater inclusion of southern activists in the analysis shows that the issue of structural adjustment was highly controversial within the anti-debt campaign. As shown in the following section, tensions, even leading to a split between northern and

38. Tim Green and Sam Clarke, "Achieving Debt Relief by 2000: Jubilee 2000 and a New Debt Coalition”, discussion paper for Jubilee 2000 Board, I May 1997. Jubilee UK archives, Newcastle. 39. Ibid.

40. While it is essential to intend to establish major trends within the Jubilee movement, one must not fall into caricature. A detailed analysis of anti-debt activists shows that dividing lines within the movement were quite blurred and cannot be simplified to a clear North-South opposition. Some organizations, although based in the Global South, were more in line with the positions held internationally by leading coalitions in the Global North (i.e. Jubilee UK and Jubilee USA) than with the ones of their southern counterparts. This is the case, for example, of Jubilee Uganda, whose founders, mostly former members of the Government of Uganda with close links with the World Bank and the IMF, were not ardent defenders of anti-imperialism and pan-Africanism. 
southern coalitions, did not result from a question of number but rather over underlying principles.

\section{"Illegitimacy" versus "unsustainability": The promotion of alternative frameworks on debt and structural adjustment}

The launch ceremony of the Jubilee Afrika campaign took place in April I998 in the capital of Ghana, Accra. This event, supported by Jubilee UK, which helped establish a Jubilee Afrika secretariat, was a crucial step in the process of internationalization of Jubilee 2000 as it officially marked the involvement of African activists in the international Jubilee 2000 movement. The African or even pan-African - dimension of the campaign was verified by the participants' countries of origin; ${ }^{41}$ only Northern Africa was absent from the ceremony, which appeared as a predominantly sub-Saharan event. Delegates came from religious organizations and churches, grass-roots organizations, development NGOs, trade unions, and political parties. For three days, African activists as well as a few international delegates attended conferences and participated in workshops to discuss the debt crisis.

Analysing the speeches delivered in Accra as well as the content of the advocacy material produced by southern coalitions gives us a good sense of how African activists framed the issue of debt and structural adjustment and to what extent these framings were different from the ones of the leading coalitions in the Global North. The major observation relates to the type of arguments developed by the different coalitions to contest international debt policies. While Jubilee USA and Jubilee UK advocated in favour of debt relief on the basis of religious and moral arguments, Jubilee Afrika mobilized primarily on historical and juridical grounds. Debt was not just "unsustainable", it was first and foremost "illegitimate". In support of their claims, African activists multiplied references to history, in particular to the periods of the transatlantic slave trade and colonization. In his keynote address at the Accra Conference, South African Archbishop Ndungane of Cape Town, who played a major role in the fight against apartheid, drew a parallel between the number of victims of slavery and of debt bondage:

It has been pointed out that in the course of the Atlantic trade in slavery 24 million people were placed in servitude. More than one and half million were thought to have died as they crossed the Atlantic Ocean. The United Nations Development Program has argued that today's debt bondage can directly account for the death of millions of children. ${ }^{42}$

4I. The ceremony gathered delegates from Ghana, Angola, Burkina Faso, Burundi, the Democratic Republic of the Congo, Sierra Leone, Kenya, Mali, Mozambique, Liberia, Nigeria, Rwanda, Senegal, South Africa, Tanzania, Uganda, and Zimbabwe.

42. Rev. Njonkonkulu Ndungane, "A Clean Slate: Africa Springboard to Hope", in Jubilee 2000 Afrika Campaign, Conference Report, April 1998. Jubilee USA archives, Washington, DC. 
While some national debts had been directly inherited from the colonial period, ${ }^{43}$ these references were primarily symbolic; debt was used as a metaphor to denounce relations of domination that were still ongoing.

Although African activists raised concerns about poverty, their discourse did not descend into pessimism. African countries were not presented as "intrinsically poor" but as having been damaged by the iniquitous policies imposed over the years by the West:

It has often been said that Afrika is poor. What nonsense! It is not Afrika that is poor. It is the Afrikans who are impoverished by centuries of exploitation and domination - so correctly said Osagyefo Kwame Nkrumah in his address of 8th August 1960 to the National Assembly as the then First President of the Republic of Ghana. ${ }^{44}$

In order to celebrate African agency, the discourse of activists was full of references to major Black historical figures, from heroes and martyrs of African independences struggles, to pan-Africanist leaders, to African-American civil rights activists. ${ }^{45}$ We found, for example, references to Mwalimu Nyerere, Patrice Lumumba, Queen Mother Moore, and Kwame Nkrumah. One of the most visible figures was Thomas Sankara, whose powerful speech against the debt hold in Addis Ababa was frequently reproduced in Jubilee Afrika advocacy material.

By making a detour through history, African activists, whose profiles will be examined below, insisted on the responsibility of former colonial powers in the impoverishment of Africa - former colonial powers, who, at the time of the campaign, were also some of the major bilateral creditors of African countries. Such a transfer of responsibility allowed activists from the Global South to go further in their claims and to turn the basic accounting question "who owes who?" upside down. On the basis of history, southern countries would not owe anything to northern creditors. If anything, they were owed. As a result, African activists did not just ask for debt "relief" or debt "forgiveness", as the leading Jubilee coalitions in the North did. They demanded "total debt cancellation" for all African countries (Figure 2).

This claim came along with a firm stance on structural adjustment. Because debt was considered "illegitimate" in the first place, no conditions were to be attached to its cancelation. African activists thus called for "the scrapping of

43. This was, for example, the case of the newly independent Democratic Republic of the Congo, which had to assume an important share of the debt contracted during the colonial period: "Le contentieux belgo-congolais", Courrier hebdomadaire du CRISP, is (1965), pp. I-25.

44. Kofi Klu, "Jubilee 2000 Afrika campaign: In Making Debt Cancellation Serve the Purpose of Poverty Eradication", paper for the conference "Poverty in Africa: A Dialogue on Causes and Solutions", Center for the Study of African Economies, Oxford, I 5-i6 April 1999.

45. Marie-Emmanuelle Pommerolle and Johanna Siméant, "African Voices and Activists at the WSF in Nairobi: The Uncertain Ways of Transnational African Activism", Journal of World-Systems Research, I6 (2009), pp. 82-93, quotation on p. 91. 


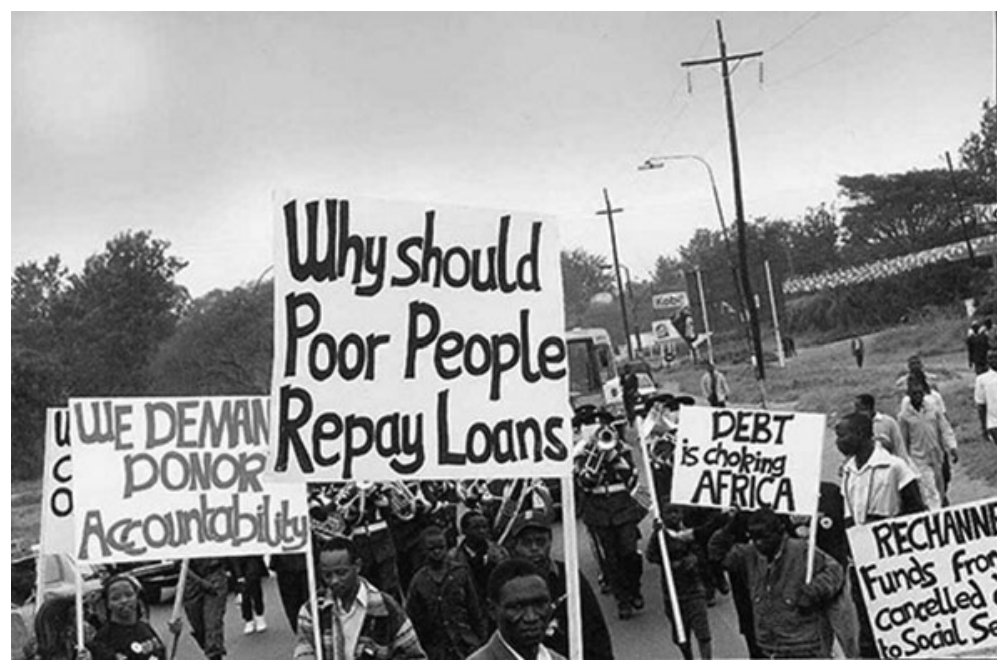

Fig. 2 Demonstration organised by the Kenyan Jubilee 2000 campaign. Source: advocacy.international.co.uk.

the HIPC initiative" and for the "immediate termination of the conditions attached to all the internationally designed debt relief mechanisms tying this to further economic adjustment".

In order to better understand the positions defended by Jubilee Africa, one must briefly discuss the social trajectories of the actors who served on its board. Such a focus is justified by the fact that this group was at the core of the Jubilee movement in Africa. They were the ones who, with the help of the Jubilee 2000 international secretariat in London, organized the conference in Accra and, later, coordinated the activities of the many member organizations at a continental level. Biographical data collected by the Jubilee 2000 international secretariat shows that the African secretariat was a small group of around ten individuals, mostly coming from Ghana (hence the Afrika spelling with a k) but also from Côte d'Ivoire and Nigeria. Although diverse in age, gender, and country of origin, they all had elitist profiles - as is often the case for the most internationalized activists; ${ }^{46}$ most of them attended university, the majority of them studying law while others studied political science, journalism, or sociology. Significantly, the secretariat included three jurists, two journalists, and two teachers. Another distinctive feature is that Jubilee Afrika members shared similar ideological backgrounds: they were all anti-imperialist, Marxist, and pan-Africanist intellectuals. At the time of 
Jubilee, all were political opponents of their national regimes. Affiong Southey, for example, had been a long-time advocate for the rights of the Ogoni people and a strong opponent of the Abacha regime in Nigeria. As for the Ghanaians, most of them initially favoured the military coups of General Jerry Rawlings (1979, I98 I). Johnny Hansen, for example, had been Ghana's Minister of Interior. Delali Yao Klu, for his part, was one of the directors of the People's Defence Committee (PDCs) of the Volta Region, in charge of its press, information, and education. But both of them resigned in 1982 when the Provisional National Defence Council (PNDC) announced the signature of an SAP with the IMF, a decision they perceived as a betrayal. This leads us to their last common feature: all Jubilee Afrika secretariat members had played a leading role, within their respective national frameworks, in the protests against the implementation of structural adjustment programmes. Affiong Southey, for example, was one of the leaders of the National Association of Nigerian Students, and Iddrisu Fuseini was a leading member of the Transport Workers of the Trade Union Congress. Their opposition to neoliberal economic reforms appeared to be costly, and many of them were subjected to strong political pressure. Some were even forced into exile: Delali Yao Klu fled to Togo and Nigeria before returning to Ghana in the early I990s, and Affiong Southey and Kofi Klu fled to the United Kingdom where they were granted refugee status.

For these activists, the emerging Jubilee 2000 campaign provided an unexpected opportunity to reinvigorate the struggle against the economic reforms induced by the SAPs while benefiting from international resources, audience, and protection. In their view, debt and structural adjustment programmes needed to be tackled side by side, as two faces of the same coin. But as the year 2000 approached, opportunities for African activists to oppose economic reforms imposed by IFIs within the anti-debt movement narrowed; at the international level, the issue of SAPs faded into the background as Jubilee 2000 leaders decided to focus their efforts on obtaining concrete debt relief agreements. The legislative strategy adopted by Jubilee USA embodied the directions taken by the anti-debt campaign. As shown below, its analysis allows us to get a better handle on the conflicts that divided anti-debt activists using a concrete case.

\section{Structural adjustment: A bone of contention within Jubilee 2000}

In the years following the launch of Jubilee 2000 , the issue of structural adjustment tended to become a major bone of contention between southern and northern campaigners. As explained in the first section, it would be unfair to say that Jubilee activists in the North did not care about structural adjustment reforms. They did. But as the campaign advanced and as the year 2000 approached, Jubilee 2000 leaders tended to favour intense direct lobbying with $\mathrm{G}_{7}$ finance ministers and IFI officials, a choice that generated fierce 
debates among northern campaigners in the North but which, above all, precipitated the rupture with their southern counterparts. Jo-Marie Griesgraber, current executive director for the New Rules for Global Finance Coalition and former executive-committee director of Jubilee USA, remembers:

We had a terrible struggle inside the group as to how to go about it. Especially when it looked like we were beginning to make progress and that it was really becoming an issue with legs, going to make a difference [...] how to articulate that? Should we go and just say cancel it, no conditions and cancel the debt now? Or say, well, that's not possible, so we will have to recognize that there will be some conditions on debt reduction, and it will be debt reduction not complete cancellation. ${ }^{47}$

In the United States, internal discussions resulted in the creation of a "legislative group" whose main goal was to pass legislation in favour of debt relief in the US Congress. As Gerald Flood, a senior policy adviser for the US Catholic Bishops Conference and prominent member of Jubilee USA, explained, "[w]e wanted to get something substantial by the end of 2000 "..$^{8}$ For a few months, members of the legislative group met on average once a week to draft the bill. Because they "felt that realistically, getting the Congress, the Administration, the G7, the IMF and the World Bank to agree to scrap the initiative and start afresh would be an impossible task", they decided to focus on "amending the existing framework", that is, the HIPC initiative, by shortening the waiting period for countries to receive debt relief, redefining debt sustainability, and broadening the eligibility criteria. Rather than trying to delink debt and structural adjustment, legislative group members chose to speak in broad terms of changing the nature of conditionality to have a greater focus on poverty reduction. Introduced in Congress by Representative Jim Leach (R-Iowa) on I I March 1999, the bill provoked indignation and anger among anti-debt activists, especially (but not exclusively) in the Global South. Thus, at a conference held in Montreal in October 2000, Ann Pettifor, a member of the Jubilee international secretariat and director of the Jubilee 2000 campaign, expressed her disapproval of the Jubilee USA strategy:

In the UK we avoided "playing god" by backing particular debt relief initiatives; or by listing countries that required debt cancellation. While we did produce a list for guidance, and as a way of highlighting the inadequacies of creditor initiatives, we argued strongly that decisions about eligibility had to be taken by independent arbitrators. This approach did not always prevent us from making errors. However, it did protect us from the approach followed by our friends in the US coalition who fell full [sic] of NGO lobbyists ("ledgers") on Capitol Hill who

47. Interview with Jo-Marie Griesgraber, Center of Concern/Jubilee USA, Washington, DC, June $20 \mathrm{II}$.

48. Interview with Gerald Flood, US Catholic Bishops Conference/Jubilee USA, Washington,

DC, June $20 \mathrm{II}$. 
promoted debt relief initiatives (notably the Leach Bill) acceptable to Republican Senators (because the Bill endorsed structural adjustment programs), but which were inimical to southern civil society. It helped to split, turn off and immobilize campaigners in the US and divided the movement internationally. ${ }^{49}$

For their part, Jubilee African activists intended to impede the passage of the law by addressing a letter to US congressional representatives in which they laid out the reasons for their opposition to the "Leach Bill":

We appreciate the efforts of legislators like Representative Jim Leach, and commend them for their leadership on this important issue. However we must point out that Mr. Leach's legislation contains a fatal flaw: it leaves multilateral debt relief in the hands of the International Monetary Fund (IMF) and continues to enforce the current link between access to multilateral debt relief for impoverished countries and compliance with harsh IMF structural adjustment austerity programs [...] We respectfully ask that the US Congress decline to support the multilateral debt proposal contained in the bill sponsored by Representative Leach. While undoubtedly well-intentioned, these provisions would eventually have an adverse impact in Africa and in other impoverished regions of the world. ${ }^{50}$

Affiong Southey and Kofi Klu (members of the Jubilee Afrika secretariat) were among the signatories, along with Dennis Brutus (a well-known antiapartheid activist and honorary president of Jubilee Afrika) and Guillaume Soro (then General Secretary of the Student Federation of Ivory Coast - FESCI).

The tone was more virulent when criticisms were directly addressed to Jubilee USA activists. As shown by the following email, criticisms concerned both the content (a bill that did not oppose structural adjustment) and the form (the lack of coordination with southern activists):

It is unthinkable for any campaign using the banner "Jubilee" and/or debt cancellation to propose to those who claim to be our creditors that they should continue on with policies and conditionalities such as Structural Adjustment Programs and HIPC which oppress us and literally cost us millions of lives each year. Likewise, it is unthinkable that any organization would propose legislation which reinforces and validates our oppression without first consulting with us and giving us the opportunity to oppose such legislation first, not after the fact. ${ }^{\text {sI }}$

Over time, the feeling was exacerbated among African activists that the domination of the Global North - which the Jubilee 2000 international secretariat denounced in its advocacy material while talking about international economics - was being reproduced within the Jubilee network itself. Indeed, the Jubilee 2000 campaign encompassed strong divergences in terms

49. Ann Pettifor, "Jubilee 2000 and the Multilateral Institutions", paper presented at the International Forum, Montreal, I-3 October 2000. Jubilee USA archives, Washington, DC.

50. Jubilee Afrika secretariat, "Letter to US Congress Representatives". Jubilee USA archives, Washington, DC.

5. Art Seroti, email to Jubilee USA, 6 April 1999. Jubilee USA archives, Washington, DC. 
of power and resources between participants, here again especially though not exclusively between the Global North and the South. ${ }^{52}$ While the Jubilee Afrika campaign struggled to make ends meet, Jubilee UK relied on a budget of $£_{2}$ million. Gradually, a "We, people from the South" formed in opposition to a "Them, people from the North".

\section{Jubilee South and the ongoing revolt of adjusted people}

In June 1999, $\mathrm{G}_{7}$ leaders gathered in Cologne and agreed on a new debt relief initiative: the enhanced Heavily Indebted Poor Countries initiative, or HIPC II. This initiative marked a change in development paradigms; ownership, good governance, and the fight against poverty became the new pillars of the emerging post-Washington Consensus. ${ }^{33}$ While this new rhetoric had concrete consequences - beginning with an increase in IFIs' legitimacy - its impact on international debt policies remained marginal. ${ }^{54}$ HIPC II mainly consisted of an overhaul of the first HIPC initiative, which, while keeping the same general framework, aimed at providing "broader, deeper, and faster" debt relief. The specifics included an increase in the number of eligible countries, a shortening of the qualifying period from six to three years, and the sale of IMF gold to fund multilateral debt relief. As for the new focus on poverty reduction, governments seeking to benefit from debt reduction were required to adopt Poverty Reduction Strategy Papers (PRSPs). ${ }^{55}$ Standardized both in form and in content, ${ }^{56}$ PRSPs did not consist of a major reorientation of the policies promoted by structural adjustment packages. Liberalization and privatization remained the hallmarks, while the fight against poverty mainly consisted in the strengthening of safety nets for the most vulnerable. ${ }^{57}$

Although the campaign was not over at that time - the deadline had been fixed at the end of the year 2000 - the design of the new international debt relief

52. Tensions were also high between the two leading coalitions of the Jubilee 2000 campaign, Jubilee USA and Jubilee UK.

53. For a detailed analysis of the trajectories of the post-Washington Consensus in Mali, see Isaline Bergamaschi, Le consensus post Washington au Mali. Trajectoires, usages et processus d'appropriation, (Ph.D., Sciences Po, 20I I).

54. Jean-Pierre Cling et al., "La Banque mondiale, entre transformations et resilience", Critique internationale, 53 (201 I), pp. 43-65.

55. Thomas Callaghy, Innovation in the Sovereign Debt Regime: From the Paris Club to Enhanced HIPC and Beyond, World Bank Operations Evaluation Department working paper, Washington, DC, 2004.

56. The staffs of the IMF and the World Bank produced guidelines to "help countries implement this new approach": IMF, IDA, "Poverty Reduction Strategy Papers - Status and Next Steps”, I 9 November 1999. Available online at: https://www.imf.org/external/np/pdr/prsp/status.htm; last accessed 23 February 202I; Brian Ames et al., "Macroeconomic Policy and Poverty Reduction", PRSP Sourcebook, ch. 6, 2 April 200I.

57. Jeremy Gould, The New Conditionality: The Politics of Poverty Reduction Strategies (London, 2005). 
initiative gave a good sense of what would be achieved by Jubilee 2000 campaigners. For southern activists, it proved that the strategy pursued by their northern counterparts and leaders in the global campaign was biased towards limited and non-radical changes.

And, indeed, Jubilee 2000 campaigners reacted very differently from the Cologne announcement. On the one hand, northern Jubilee coalitions were - with a few exceptions - lukewarm. Although they did not welcome HIPC II with enthusiasm, their criticisms focused mainly on the specifics: the new debt relief initiative did not go far enough. On the other hand, southern Jubilee coalitions denounced the initiative as a whole:

Jubilee South sees nothing to welcome in this initiative. This Köln scheme, like its predecessors, refuses to acknowledge the moral dimensions of the debt crisis and the historical responsibility of the rich countries for the current state of affairs..$^{8}$

Here, again, the question was not one of numbers but one of underlying principles:

The Köln Debt Initiative does not offer relief for the 4.5 billion women and men in the South who suffer from debt domination. It makes a mockery of their right to a dignified life. "Expanded HIPC" means increased misery and debt for peoples of the south. "Expanded HIPC" means increased misery and debt for peoples of the South. HIPC is fundamentally flawed because it is linked to Structural Adjustment Programmes. These programmes have been shown to have a devastating human impact on account of diminished spending capacities for social services and job creation. ${ }^{59}$

Criticized for legitimizing debt, HIPC II was also accused of sowing division among the countries of the South by drawing a line between those who would benefit from debt relief and the others:

We reject all schemes of the North that divide peoples of the South. We refuse to be categorized as "highly indebted poor countries" or "moderately indebted countries" etc., all of which do not reflect the real situation of impoverishment and the excluded and exploited people in ALL South countries. ${ }^{60}$

Southern activists felt "humiliated" and held northern campaigners responsible for what they considered a "failure":

As often happens in history, good intentions are often marred by harsh realities in the ground. The movement failed to live up to the expectations of those who made the sacrifices. Charity is not always bad. But in this context, it provided the lenders with a high moral ground, and the borrowers a humiliating stance.

58. Jubilee South, “Jubilee South Rejects Köln Initiative as a Cruel Hoax”, I 8 June I 999. Jubilee USA archives, Washington, DC.

59. Ibid.

60. Jubilee South, "South-South Summit Declaration: Towards a Debt-Free Millennium", 2 I November 1999, p. 3. Jubilee USA archives, Washington, DC. 
The problem with the Jubilee 2000 Campaign was that its mainstream campaigners more unwittingly than intentionally, legitimized the debt and also by default legitimized the system that creates and perpetuates debt. Instead of challenging the debt and its underlying causes, the $\mathrm{J}_{2}$ campaigners focused on the numbers game, pushing for bigger and bigger amounts of "relief" thus, effectively, endorsing the notion that the debt was legitimate in the first place. ${ }^{61}$

Following the launch of HIPC II, tensions between northern and southern campaigners, already strong in the months preceding the $\mathrm{G}_{7}$ Cologne summit, resulted in a split within the Jubilee movement. In November 1999, a hundred southern delegates coming from Latin America, South East Asia, and Africa, as well as from the diaspora, gathered in Johannesburg where they decided to continue the struggle against debt and structural adjustment on their own under a new banner: Jubilee South. ${ }^{62}$ The leading coalitions of Jubilee South were Jubilee Argentina, Jubilee South Africa, and the Freedom from Debt coalition (the Philippines). The Jubilee Afrika secretariat also played an important role in the birth of the movement, as did the DC-based coalition so Years is Enough. The platform it published clarified and developed its position: it urged southern countries "to call for debt repudiation, for restitution, reparations and repayment of the social, historical and ecological debt due to the South, for rejection of SAPs and other conditionalities and resistance to neoliberal economic policies". ${ }^{63}$

In spite of the split, Jubilee South activists intended to continue their collaboration with their northern counterparts. On I I-I7 December 2000, they organized the first "South-North Dialogue". Held in Dakar, the event gathered a hundred anti-debt activists including delegates from Jubilee USA, Jubilee UK, and ErlassJahr (Germany). While the issues of reparations and repudiation remained contentious, all organizations agreed to work on the issue of debt illegitimacy. It is worth underlining that the CADTM, almost absent from the Jubilee 2000 campaign, lent its support to the organization of the SouthNorth Dialogue. This close collaboration between Jubilee South and the CADTM continued after the campaign ended. Both organizations took an active role in the birth of the global justice movement, of which debt became a pillar. ${ }^{64}$

61. Jubilee South, "JNorth view from JSouth: Why Jubilee 2000 Failed”, I 2 February 200 I. Jubilee USA archives, Washington, DC.

62. The creation of this new structure was the result of a process that took place over several months. Just a few months after the launch of Jubilee Afrika, members of an important Asian antidebt network, a member of Jubilee 2000, the Asian Network on Debt and Development, gathered in Hong Kong to discuss the possibility of a South-South summit on debt. Around the same time, the head of Jubilee Nicaragua made its "Proposal for a South Jubilee".

63. Jubilee South, "South-South Summit Declaration", p. I.

64. Laurence Caramel, "Les réseaux de l'antimondialisation”, Critique Internationale, I 3 (200I), pp. I53-I6I. 


\section{CONCLUSION}

Establishing the relationship between the debt crisis in southern countries and the financial crisis of 2008 in the North resembles playing a game of mirrors. From one to the other, we find a common issue: debt, and especially indebtedness. Some institutions in charge of dealing with the debt are also present in both settings, including the G8 (G7 at the time of Jubilee 2000) and the IMF, which with the Greek debt crisis makes its return in Europe. Yet other institutions are specific to each situation: the World Bank, which played a central role during the I980s and I990s, was absent from the management of the European debt crisis, while the European Central Bank, absent in the case of southern countries, played a leading role in the European crisis. In both contexts, we also find public policy mechanisms which, although not exactly alike, show significant common patterns, beginning with the firm promotion - or rather imposition - of so-called structural reforms. The latter are driven and supported by common discourses: bilateral creditors and international financial institutions in both contexts insist on the responsibility of the borrowing states, the laziness of their populations, and the incompetence or even corruption of their governments. In the post-2008 European debt crisis, the derogatory - some have said "racist" - acronym PIGS (for Portugal, Italy, Greece, and Spain), ${ }^{65}$ which was often used by financial, political, and media stakeholders, proved significant in this regard. Some NGOs or antidebt networks are also present in the two pictures: the Jubilee Debt Campaign, ErlassJahr, Eurodad, and the CADTM, which strongly advocated during the I 990 s in favour of the cancelation of the debt of southern countries, were still very much active in the post-2008 crisis. Eric Toussaint, who was involved in the campaign against debt and structural adjustment in the I990s, is one of the most renowned activists of the anti-debt and anti-austerity movements in Europe. Lastly, we can underline the use of common arguments and concepts such as "odious" or "illegitimate" debt. Enshrined in argumentative chains rooted in history and morals, such notions, which activists are still using today, were initially forged to advocate in favour of the cancelation of the debt of southern countries owed to northern countries and international financial institutions.

Fifteen years after the end of Jubilee 2000, authors of the preliminary report of the Truth Committee on the Greek Public Debt provided "evidence of indicative cases of illegal, illegitimate and odious debts", and on this basis they "presented the options concerning the cancellation of debt" and called for the "repudiation and suspension of Greek sovereign debt" ${ }^{66}$ Drawing on historical arguments, Greece's then-Deputy Finance Minister Dimitris Mardas

65. The use of the acronym goes back to 1979 and describes countries in the European Union considered to have troubled economies. It was then popularized by the financial press after 2008 . 66. The Truth Committee on Public Debt, Preliminary Report, i 8 June 201 5, p. 4. 
announced in April 20Is that, according to the country's General Accounting Office, Germany would owe Greece $€_{279}$ billion in reparations for Nazi occupation during World War II.

Of course, the two "debt crises" are not the same - not least because European and African countries do not carry the same weight on the international scene. But at a time when sovereign debt has become one of the major constraints faced by European states, and when a large trans-party consensus agrees on the necessity of sharply reducing public expenditure, making a historical and geographical detour proved to be heuristic. Taking a step to the side offered the opportunity to question the idea of the ineluctability of debt and to understand that the debt problem is neither natural nor immutable. 